\title{
Students' experiences with different learning pathways to higher professional bachelor programmes
}

\author{
Harm J.A. Biemans ${ }^{\star 1}$, Hans Mariën ${ }^{2}$, Erik Fleur ${ }^{3}$, \\ Tanya Beliaeva ${ }^{3} \&$ Jan Harbers ${ }^{4}$ \\ ${ }^{1}$ Wageningen University \& Research, Education and Learning Sciences (ELS), \\ Wageningen, Netherlands \\ ${ }^{2}$ Tilburg University, IVA Education, Tilburg, Netherlands \\ ${ }^{3}$ Department of Education, Culture and Science, Executive Agency for Education (DUO), \\ The Hague, Netherlands \\ ${ }^{4}$ Terra Groningen, Groningen, Netherlands
}

Received 20.12.2018, Accepted 29.06.2019, Published: 29.04.2020

\begin{abstract}
Context: In the Dutch educational system, different learning pathways to higher professional bachelor (or HBO) programmes have been created: the regular VET route, the general secondary education route, and continuing learning pathways (such as the Green Lyceum or GL) that combine characteristics of these two traditional routes and that are specifically designed for students who combine a relatively high cognitive level with an affinity for practical, vocation-oriented assignments.
\end{abstract}

Approach: The present study aimed to compare the experiences of students coming from these three different learning pathways to HBO. 62 former GL students, 127 former middlemanagement VET (or MBO) students, and 81 former regular general secondary education (or HAVO) students completed an online questionnaire on their experiences in their first HBO study year and their scores on the various scales were compared.

Findings: Students from the three groups were equally satisfied with their current HBO programme. The same pattern was found for perceived study success in their HBO pro-

*Corresponding author: harm.biemans@wur.nl 
gramme. Former GL students, however, mentioned that they had been better prepared in terms of development of study skills needed in $\mathrm{HBO}$. Compared with the MBO route to $\mathrm{HBO}$, former GL students felt better prepared in terms of the theoretical subjects addressed in their previous educational programme. In this regard, their level of theoretical preparation was comparable to that of former HAVO students. When the vocation-oriented aspects of education were concerned, however, the GL appeared to be comparable with the MBO route to $\mathrm{HBO}$ (in the HAVO curriculum, vocation-oriented preparation for $\mathrm{HBO}$ is absent). Moreover, former HAVO students scored lower than former GL and former MBO students with respect to the extent to which they felt that they had received support in choosing a particular $\mathrm{HBO}$ programme in their previous educational programme.

Conclusion: The GL seems to combine the advantages of MBO and HAVO programmes for this particular group of students: theoretical preparation for $\mathrm{HBO}$ at HAVO level combined with practical preparation at $\mathrm{MBO}$ level, systematic career orientation and guidance, and development of study skills required in HBO. In other words, such continuing learning pathways can be a curriculum design solution for specific student groups to promote their transition to $\mathrm{HBO}$.

Keywords: Learning pathway, transition, curriculum, educational innovation, vocational education and training, VET, Green Lyceum

\section{Introduction}

Many countries worldwide have developed and implemented an explicit educational policy to increase student numbers in higher professional bachelor (and, as a possible follow-up, professional master) programmes, as the most advanced levels in the Vocational Education and Training (VET) system (Cedefop, 2016; see figure 1). A higher educational level is regarded as crucial for new professionals to be able to meet the ever-changing demands of their future jobs and to live as responsible citizens in modern society (Dutch Educational Council, 2014; Keeley, 2007; OECD, 2010).

In the Netherlands, the country in which the present research was carried out, higher professional bachelor programmes (or higher vocational education (HBO) programmes, as these are called in Dutch) are being offered by universities of applied sciences. The name of these $\mathrm{HBO}$ institutes already indicates the nature of the particular educational programmes that are being offered to the students. On the one hand, these higher professional bachelor programmes can be characterised as building on scientific insights, and, on the other hand, they focus on application of concrete competencies (i.e., integrated sets of knowledge, skills, and attitudes (Biemans et al., 2004; Biemans et al., 2009; Mulder, 2017)) in professional contexts. 
HBO graduates, in other words, should be able to analyse specific professional contexts and, at the same time, to act accordingly and efficiently in practical, vocation-related situations.

Traditionally, in the Dutch educational system, two different pathways lead to higher professional bachelor programmes at EQF levels 5 or 6 (HBO; nominal duration: 2-4 years) (see figure 1; Cedefop, 2016):

1. The VET route, starting from lower secondary pre-vocational school-based programmes at EQF level 2 (VMBO; 4 years) via middle-management VET programmes at EQF level 4 (MBO; 3-4 years) to $\mathrm{HBO}$;

2. The general secondary education route, i.e., integrated lower and upper general secondary programmes at EQF level 4 (HAVO; 5 years) leading to HBO.

Although the EQF levels of both routes are comparable, there are clear differences as well. The VET route to HBO is relatively long (7-8 years in total) and has a strong vocational and practical orientation on the particular sector of the labour market (e.g., engineering, communication, agriculture), while the general secondary education route is more theory-oriented, hardly focussed on specific professional domains, and relatively short in nominal duration (5 years), which makes the students younger when they enter HBO (without study delay in primary or secondary education they will be 17 or 18 years old).

There are strong indications, however, that these two traditional routes to $\mathrm{HBO}$ are not optimal for a considerable group of students with high potential to successfully follow HBO programmes (see also Van den Berg, 2013). First of all, this group of students can be characterised as ambitious. They see a diploma for a higher professional bachelor (or maybe even master) programme as the ultimate goal in their study career. Moreover, they have been assessed in primary education as having relatively high cognitive learning abilities (study advice for secondary education EQF level 4). Finally, a third crucial characteristic of these students is that they do not only want to be challenged cognitively but that they prefer to be engaged in practical, vocation-related assignments in their educational trajectory as well (cf. Jäppinen \& Maunonen-Eskelinen, 2012). For this specific category of students, the theoretical level of the VET route to HBO might not be challenging enough and this route might also be too long to keep them focussed on reaching the HBO level in the end. The general secondary education route, however, might not be motivating enough for them either, given the highly theoretical curriculum and the lack of practical, work-related assignments. As a consequence, these students might get stuck in the two traditional pathways to $\mathrm{HBO}$, with study delay and potential drop-out as a result (see also Biemans et al., 2016). 


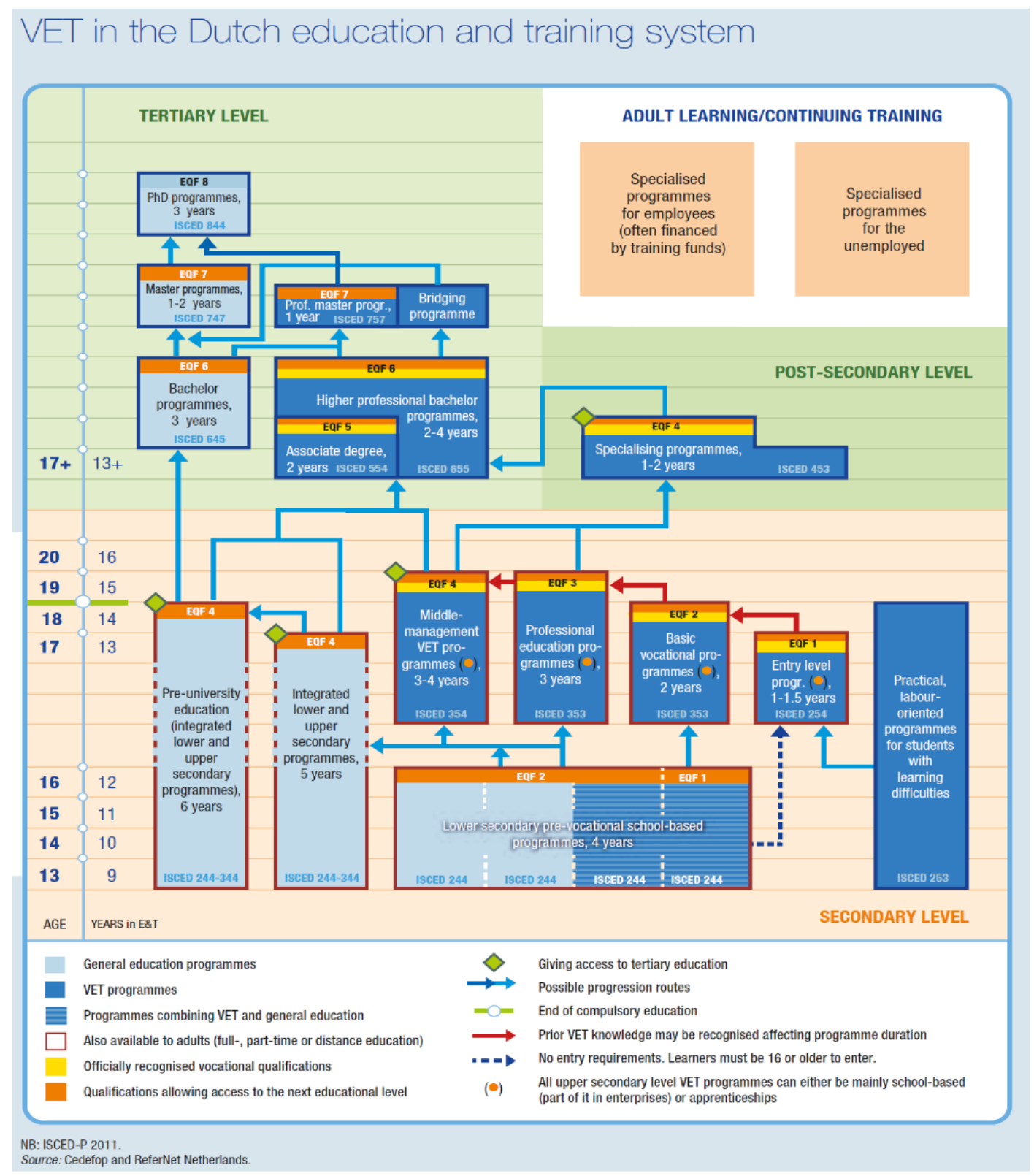

Figure 1: VET in the Dutch education and training system (Cedefop, 2016)

Therefore, in addition to the two traditional routes to higher professional bachelor programmes mentioned above, alternative learning pathways that combine characteristics of these two already existing routes have been designed and implemented in the Netherlands during the last decade to meet the specific characteristics and preferences of this category of students (see also Biemans et al., 2013). These so-called continuing learning pathways in VET com- 
bine the theoretical level of the general secondary education route to $\mathrm{HBO}$ with the practiceoriented nature of the VET route in a new curriculum of integrated and accelerated VMBO and $\mathrm{MBO}$ programmes (as shown in figure 1, these three types of learning routes including the new continuing learning pathways in VET concern educational programmes at the secondary level for students in the age of 13-20 leading to higher professional bachelor programmes at the tertiary level and should not be confused with adult learning programmes). This Dutch trend of designing and implementing continuing learning pathways is in line with the efforts many other countries are making to make access routes to higher education new and more flexible and, thus, to promote students' transitions between successive educational levels (see e.g., Catterall et al., 2014; Harris \& Rainey, 2012; Hoelscher et al., 2008).

A prototypical example of such continuing learning pathways in the Netherlands is the Green Lyceum (or GL), implemented by agricultural VET institutes, which explains the label 'Green'. The GL curriculum combines a VMBO programme and a MBO programme at EQF4 level in an integrated learning trajectory and is characterised by a nominal duration of 6 years in total (instead of the regular 7 to 8 years; further acceleration to 5 years is an additional option for talented students).

The present study will focus on the GL as a possible alternative pathway to HBO. Previous research (Biemans et al., 2019) already demonstrated that former GL students more often proceeded with an $\mathrm{HBO}$ programme than comparable students coming from regular MBO. The central aim of the present study was to examine former GL students' experiences in HBO and to compare those with the experiences of students coming from the two traditional routes to $\mathrm{HBO}$ mentioned above. After all, a successful $\mathrm{HBO}$ career could be considered as the ultimate goal of continuing learning pathways such as the GL. In this way, the present study aimed to contribute to knowledge on students' learning experiences in different pathways to higher professional bachelor ( $\mathrm{HBO}$ ) programmes at the tertiary level (see figure 1) and to lead to deeper insights in how students' transitions to this educational level can be promoted through learning pathways with specific educational design features.

\section{Theoretical background}

\subsection{Transition to and drop-out from higher professional bachelor pro- grammes}

Transitions between successive educational levels of the VET system (but also in other segments of the educational system) appear to be problematic for many students. As described by Biemans et al. (2019), this phenomenon has been analysed in the international literature 
on the permeability of educational systems (e.g., Bathmaker \& Thomas, 2009; Bradley, 2008; Gorard et al., 2006; Watson, 2006).

One of the key aspects of permeability of educational systems is the 'capacity of education and training systems to enable learners to access and move among different pathways (programmes, levels) and systems' (Cedefop, 2014, p. 193). In many cases, the permeability of educational systems is suboptimal and even if there are hardly any institutional barriers between successive levels, it is often very difficult for students to relate and integrate the educational programmes of the different levels or to adjust to the particular requirements of the new programme. Such transition problems may lead to highly stressful experiences of the students and feelings of disconnection with their new educational programme and learning environment (Mulder, 2016), resulting in less successful study careers and substantial drop-out rates (Wheelahan, 2008). The personal and societal costs of these drop-out rates are substantial and hamper governmental policies to enhance the general educational level and the upward educational mobility and limit future study and job opportunities of the students (Cedefop, 2014; Keeley, 2007; SCP, 2016).

Transition problems between educational levels resulting in relatively high student dropout rates have been reported in many countries. For example, Hoelscher et al. (2008) discussed students' transitions from vocational education and training to higher education (HE) in the United Kingdom and examined whether participation in VET provides a successful progression route into tertiary education. In this regard, it should be noted that UK VET policy has as one of its explicit aims to increase access to higher education via this route. Based on their research, they concluded (p. 150) that, so far, 'neither attempts to create stronger links between HE and VET programmes, nor to change perceptions of potential applicants through outreach, have resulted in evenly distributed access to HE [....] and that policy instruments need to intervene earlier in individuals' educational pathways' to achieve this goal and to really foster students' transitions to tertiary education.

Comparable conclusions were drawn with respect to learning pathways from vocational education and training to higher education in Australia by Catterall et al. (2014) and Harris and Rainey (2012). Catterall et al. (2014) reported that, although an increase in students who entered HE following their studies in the VET sector could be determined, 'the transition period, particularly the first semester of study, is an unnecessarily stressful time for many students' (p. 242). In line with this conclusion, Harris and Rainey (2012) claimed that, although seamless pathways for learners between successive educational levels are being promoted by governments in many countries, learners' actual experiences in their educational journeys have been neglected to a high extent, both in policy and in research.

This article especially deals with the transition to higher professional bachelor (HBO) programmes at the tertiary level in the Netherlands (see figure 1) and the experiences of students in their first HBO study year, which can be regarded as indications for their study careers in 
HBO. Mulder and Cuppen (2018) did an extensive study on the transition to HBO, student drop-out from HBO programmes and possible factors that could explain this phenomenon. When the influx of students in Dutch HBO in the last 5 years (2013-2018) was concerned, about 30\% had done their previous education in regular MBO at EQF4 level and about 53\% in regular general secondary education at EQF4 level (HAVO) while the remaining 17\% had followed other, less conventional routes (e.g., pre-university education at EQF4 level).

Of the students with a background in $\mathrm{MBO}$, about $22 \%$ appeared to have dropped out after the first year (i.e., did not appear to follow any educational programme after the first $\mathrm{HBO}$ year). According to the Association of Universities for Applied Sciences (2016), this drop-out rate of $22 \%$ after one year even increased to a drop-out rate of about $31 \%$ of the former MBO students after three years (see also Sneyers \& De Witte, 2016). In many cases, these students decide to enter the labor market with their MBO diploma. With respect to the former HAVO students, drop-out rates after one year and after three years were $12 \%$ and $16 \%$ respectively (if they are not successful, these students tend to switch to another educational programme). Thus, in the first phase of the $\mathrm{HBO}$ trajectory, the drop-out rates from $\mathrm{HBO}$ of former $\mathrm{MBO}$ students were considerably higher than the drop-out rates of former HAVO students. Study success rates of former MBO and HAVO students after five years, however, were comparable: Only $45 \%$ of the students from both groups had finished their HBO programme with a diploma within a period of five years (the nominal study period of these professional bachelor programmes is 4 years). These figures appeared to depend on different factors such as gender and ethnical background of the student, educational level of the parents, performance and effort level of the student, and type of HBO programme (Association of Universities for Applied Sciences, 2016; see also Mulder \& Cuppen, 2016; Sneyers \& De Witte, 2016).

Thus, the conclusion can be drawn that drop-out and study delay are serious problems in $\mathrm{HBO}$ programmes, both for former MBO students and for former HAVO students, although the reasons may differ for both groups. For former HAVO students, the practical, workrelated aspects of the curriculum might cause difficulties because they have hardly had any experience with comparable tasks in their previous educational programme, as opposed to former MBO students. For them, on the other hand, the theoretical level of the HBO curriculum might be hard to handle because their previous education had been more practical and less theory-oriented by nature. Thus, both groups of students seem to experience their own challenges in $\mathrm{HBO}$. Crucial issues in this regard are the lack of curriculum continuity between the respective curricula and the absence of integration of these educational programmes (see also Biemans et al., 2019).

Mulder and Cuppen (2018) identified additional factors that are related to drop-out from HBO. Students who dropped out from an HBO programme (or switched to another educational programme) felt much less at home with their teachers, educational programme, fellow-students, and educational institute than students who decided to proceed. This ap- 
peared to be true both for former MBO and for former HAVO students. Moreover, drop-out students reported that they would have preferred more contact with their fellow students, teachers, study coach and advisor, and their mentor. In short, they felt less connected with their educational programme (see also Mulder, 2016). They reported that, already at the beginning of their HBO study programme, they had more doubts regarding their study choice and had given this process less consideration, had collected less information on their study programme and felt less motivated to complete their educational programme (see also Mulder, 2018; Kuijpers et al., 2011; Winters, 2012).

Regarding the didactical methods adopted in $\mathrm{HBO}$, the required study skills, and the content of their $\mathrm{HBO}$ subjects, both former $\mathrm{MBO}$ and HAVO students reported to experience a poor alignment with their own specific skills (see also Jäppinen \& Maunonen-Eskelinen, 2012). In addition, as compared to former HAVO students, former MBO students reported that they felt less prepared with respect to calculation skills, writing skills, Dutch language, and the way of testing in HBO. During their HBO programme, students who would drop out later, reported that they experienced more difficulties to spend efforts on subjects they considered to be less interesting, showed the tendency to postpone study tasks, and had more problems with planning their learning tasks (Mulder, 2018; Mulder \& Cuppen, 2018).

To summarize, various factors might give an indication of a student's study career in HBO such as motivation, wellbeing, and satisfaction of the student regarding his or her present $\mathrm{HBO}$ programme, (perceived) study success in $\mathrm{HBO}$, (perceived) quality of the previous educational programme and the extent to which students feel that they have been prepared for $\mathrm{HBO}$, and to what extent they have developed necessary study skills, reached the required theoretical level, had sufficient practical preparation, and received support in choosing their present $\mathrm{HBO}$ programme. These factors might be different for different categories of students in $\mathrm{HBO}$, in particular for students coming from different routes such as MBO and HAVO. Former MBO students might feel less prepared for the theoretical level of the HBO curriculum but better prepared for the practical, vocation-oriented aspects while, for former HAVO students, it might be the other way around.

\subsection{Continuing learning pathways to HBO: the best of both worlds?}

As mentioned in the Introduction section, in addition to the two traditional routes to $\mathrm{HBO}$, namely the VET route (MBO) and the general secondary education route (HAVO), alternative learning pathways that combine characteristics of these two pathways have been designed and implemented to meet the characteristics and preferences of a specific and significant student category: students who combine a relatively high cognitive level (as indicated by a primary school advice for follow-up education at EQF 4 level) with an outspoken affinity for practical, vocation-oriented assignments and who have clear ambitions to proceed with 
an HBO programme. For these students, HAVO would fit with their cognitive level but this type of education lacks a specific vocational orientation and does not allow students to apply their knowledge and skills in practical situations. $\mathrm{MBO}$, on the other hand, does provide this practical orientation but might not offer enough cognitive challenges for them to keep them motivated and to prepare them for the theoretical level of an HBO programme.

To solve the above-mentioned problems of discontinuity and disintegration and to improve transition to and promote study success in higher education, continuing learning pathways have been introduced in educational systems worldwide as curriculum design solutions (e.g., Harris \& Rainey, 2012; Jäppinen \& Maunonen-Eskelinen, 2012; Sneyers \& De Witte, 2016). Continuing learning pathways can be defined as 'sequential educational programmes combined into a new [integrated] educational programme: Continuing [learning] pathways are characterised by curriculum continuity in particular competence areas or subjects lasting several years, and encompassing more than one qualification level' (Biemans et al., 2013, p. 109). According to Biemans et al. (2016, p. 316), 'the aim of these continuing [learning] pathways is to ensure curriculum continuity [and integration] of successive educational programmes and, thus, to promote and streamline students' knowledge and skill acquisition and competence development' (cf. Brockmann et al., 2008). In this way, so-called competence progression models for specific content domains can be implemented to ensure students' continuing competence development (Biemans et al., 2019). For example, Lilleväli and Täks (2017, p. 3) elaborated on the concept of a competence progression model within the context of entrepreneurship education (or EE) as 'a step-by-step advancement in various contexts and with learning outcomes and roles of EE throughout the education system' (see also Rasmussen \& Nybye, 2013).

In the Netherlands, many educational innovations have been carried out stimulated by governmental policy (see e.g., Dutch Educational Council, 2014; Sneyers \& De Witte, 2016) to create continuing learning pathways aimed at connecting various VET levels (see also figure 1). A critical and prototypical example is the so-called Green Lyceum or GL, which was implemented by agricultural (or 'green') VET institutes as one of the first continuing learning pathways in the Dutch educational system in 2007 and is currently offered by 13 schools of 6 agricultural VET institutes to about 1,300 students (see also Van den Berg et a.2017). The GL as an experimental pathway to promote the transition of students to $\mathrm{HBO}$ will be the focus of this article. In other sectors of the Dutch VET system, more or less comparable initiatives in terms of educational design characteristics can be found, such as the programme Talent Development Technical Sciences (or TOT), the Professional HAVO Human Technology, and the Top Trajectory Social Work (see also Imandt et al., 2016).

The GL is characterised by a combination of educational design features (see for detailed information on GL design features and theoretical embedding Biemans et al., 2016; 2019). As mentioned above, this learning pathway combines a VMBO programme and a $\mathrm{MBO}$ pro- 
gramme at EQF4 level in an integrated learning trajectory with a nominal duration of 6 years (instead of the regular 7 to 8 years). Further acceleration of the GL programme to 5 years is possible, depending on the progress of the individual student as shown by his or her portfolio. The ultimate goal of the GL is to prepare the students for a successful study career in HBO. Therefore, already during the GL intake procedure, the students' ambitions and competencies are being questioned. Moreover, the theoretical level of the GL and the specific learning and research competencies that are being developed, are attuned to $\mathrm{HBO}$ to facilitate a future transition. In addition, vocation-oriented assignments in different sectors depending on the student's preferences and future plans are being offered throughout the GL trajectory and career orientation and guidance play a central role in this decision-making process to be able to design a tailor-made programme for the individual student. Although the GL is offered by institutes for agricultural education, it is characterized by a broad focus on all possible $\mathrm{HBO}$ domains and students are free to choose their own preferred sector.

\subsection{Study aim and research questions}

Previous research (Biemans et al., 2019) already demonstrated that former GL students more often proceeded with an $\mathrm{HBO}$ programme than comparable students coming from regular MBO. In line with the broad focus of the GL, former students from this learning route less often chose for 'green' HBO programmes than comparable students coming from regular agricultural MBO. Instead, they opted for a follow-up study in almost all possible HBO sectors.

In the present research, former GL students were subject of study in the first year of their $\mathrm{HBO}$ programme. As mentioned in the Introduction, the central aim of this study was to examine former GL students' experiences in $\mathrm{HBO}$ and to compare those with the experiences of students coming from the two traditional routes (i.e., regular $\mathrm{MBO}$ at EQF4 level and regular general secondary education at EQF4 level (HAVO)). As mentioned in the Introduction, the present study aimed to contribute to knowledge on students' learning experiences in different pathways to higher professional bachelor $(\mathrm{HBO})$ programmes at the tertiary level (see figure 1) and to lead to deeper insights in how students' transitions to this educational level can be promoted through learning pathways with specific educational design features.

To be specific, this study aimed to provide answers to the following research questions:

1. Do these three categories of students (former GL, former MBO, and former HAVO students) differ in motivation for and perceived success in their present $\mathrm{HBO}$ programme?

2. Do these three categories of students differ in appreciation for and satisfaction with their previous educational programme? 
3. Do these three categories of students differ in the extent to which they feel prepared for their $\mathrm{HBO}$ programme in their previous educational programme?

\section{Method}

\subsection{Participants and groups}

The group of former GL students is only a small subgroup of all students who start a higher professional bachelor (HBO) programme. Yearly, almost 50,000 students start a study at HBO level after completing general secondary education at EQF4 level (HAVO) and more than 30,000 after graduating from the highest level of secondary vocational education (MBO EQF4), thus providing broad samples to select two groups of students who resemble the former GL students as much as possible. Both in 2016 and in 2017, a group of 600 students was selected who had completed HAVO. Moreover, a group of 238 students who had completed MBO was invited to participate. The selected former HAVO students had all attended a school in the same region as the GL students, and the selected former MBO students came from the same institutes as the 84 former GL students. All students were asked to complete an online questionnaire on their experiences in the first year of their HBO study (former GL and MBO students received a reminder by phone as their phone numbers were available, which explains the higher response rates for these groups).

Participants in the present study were 270 students (131 males, 139 females; average age: 19.5 years old) who had all chosen an $\mathrm{HBO}$ programme after graduating from their previous educational programme and who were in the second half of the first year of their HBO programme during data collection in 2016 or 2017. To be specific, 62 former GL students from 2 Dutch agricultural VET institutes (28 males, 34 females; average age: 18.1 years old) were compared with 127 former regular EQF4 MBO students ( 73 males, 54 females; average age: 21.0 years old) and 81 former HAVO students ( 30 males, 51 females; average age: 18.2 years old) who had chosen for a follow-up study in comparable domains at the same HBO institutes as the former GL students.

\subsection{Instrument and analyses}

Students' experiences in the first $\mathrm{HBO}$ programme year were collected through an online questionnaire that consisted of nine scales. Several scales had already been composed and verified in previous research (see e.g., Biemans et al., 2013). The items corresponding with the various scales were presented to the students in separate blocks. Students had to use fivepoint Likert scales $(1=$ minimal score; $5=$ maximal score $)$ to respond to the various items. 
Afterwards, the structure of the scales was empirically verified through factor analysis and reliability analysis. The reliability of the various scales turned out to be satisfactory to very high (see a values mentioned below). The scales of the questionnaire were:

- Motivation for school (2 items, e.g., 'If I had to select an educational programme all over again, I would choose this particular programme'; $\alpha=0.71)$ (RQ1);

- School wellbeing (15 items, e.g., 'I enjoy attending this educational programme'; $\alpha=0.88$ ) (RQ1);

- School satisfaction (3 items, e.g., 'I am supported well if I experience learning problems'; $\alpha=0.78)$ (RQ1);

- Perceived study success in HBO programme (5 items, e.g., 'I am well on track in my educational programme'; $\alpha=0.85)(\mathrm{RQ} 1)$;

- Satisfaction with previous educational programme (11 items, e.g., 'My previous educational programme was a good preparation for my present $\mathrm{HBO}$ programme; $\alpha=0.83$ ) (RQ2);

- Extent to which specific study skills required in their HBO programme were developed in their previous educational programme (10 items, e.g., presenting, using ICT, reflecting; $\alpha=0.83$ ) (RQ3);

- Extent to which students feel prepared for their HBO programme in their previous educational programme with respect to specific theoretical subjects (8 items, e.g., Dutch and English language, mathematics; $\alpha=0.77$ ) (RQ3);

- Extent to which students feel supported in choosing a specific HBO programme in their previous educational programme (7 items, e.g., contacts with study coach and advisor; $\alpha=0.80)(R Q 3)$;

- Extent to which students feel prepared for the vocation-oriented aspects of their HBO programme in their previous educational programme (5 items, e.g., internships; $\alpha=0.66$; only relevant for former GL and MBO students) (RQ3).

Mean scores of the three groups (former GL, former MBO, and former HAVO students) were compared for eight questionnaire scales mentioned above through a MANOVA procedure with Gender as a covariate to control for possible gender differences (see Howell, 2010) (for the scale Vocation-oriented aspects, a separate univariate analysis of variance with the two groups former GL and former MBO students was carried out because former HAVO stu- 
dents did not have scores for this scale since vocation-oriented aspects had been absent in their educational programme). If an overall significant difference between the three groups was found for a particular scale, simple contrast analyses were carried out to make pairwise comparisons between the various groups.

\section{$4 \quad$ Results}

With respect to the first research question ('Do the three categories of students (former GL, former $\mathrm{MBO}$, and former HAVO students) differ in motivation for and perceived success in their present $\mathrm{HBO}$ programme?'), no significant differences in mean scores between students from the three groups were found for the scales Motivation for school $(F(2,269)=2.12$; $\mathrm{p}=0.12)$, School wellbeing $(\mathrm{F}(2,269)=0.57 ; \mathrm{p}=0.57)$, School satisfaction $(\mathrm{F}(2,269)=1.17$; $\mathrm{p}=0.31)$, and Perceived study success in HBO programme $(\mathrm{F}(2,269)=2.36 ; \mathrm{p}=0.10)$. Students from the three groups all scored relatively high on the various scales but no significant differences were found between former GL, former MBO, and former HAVO students in motivation for and perceived success in their present $\mathrm{HBO}$ programme (see also table 1).

Table 1: Mean scores (M) and standard deviations (Sd) of former GL, former MBO, and former HAVO students for the questionnaire scales Motivation for school, School wellbeing, School satisfaction, and Perceived study success in HBO programme

\begin{tabular}{|l|c|c|c|c|}
\hline & $\begin{array}{c}\text { Motivation for } \\
\text { school }\end{array}$ & School wellbeing & $\begin{array}{c}\text { School } \\
\text { satisfaction }\end{array}$ & $\begin{array}{c}\text { Perceived study } \\
\text { success in HBO } \\
\text { programme } \\
\mathrm{M}(\mathrm{Sd})\end{array}$ \\
\hline Former GL & $4.19(1.07)$ & $3.88(0.50)$ & $3.88(0.60)$ & $3.87(0.77)$ \\
\hline Former MBO & $4.42(0.92)$ & $3.83(0.53)$ & $3.80(0.72)$ & $3.67(0.86)$ \\
\hline Former HAVO & $4.15(0.92)$ & $3.78(0.51)$ & $3.70(0.75)$ & $3.91(0.81)$ \\
\hline
\end{tabular}

Regarding the second research question ('Do the three categories of students differ in appreciation for and satisfaction with their previous educational programme?'), the three groups of students indeed appeared to differ in their mean score on the corresponding scale of the questionnaire $(\mathrm{F}(2,269)=3.33 ; \mathrm{p} \leq 0.05)$. Post hoc tests revealed significant differences between former GL students and former MBO students ( $\mathrm{p} \leq 0.05)$, and between former HAVO students and former MBO students $(\mathrm{p} \leq 0.05)$. Both former GL students and former HAVO students appear to be satisfied to a higher extent with their previous educational programme than former MBO students were, although this last category of students scored on the positive side of the scale as well. No significant differences were found in this regard between former GL and former HAVO students ( $\mathrm{p}=0.81$ ) (see also table 2). 
Table 2: Mean scores (M) and standard deviations (Sd) of former GL, former MBO, and former HAVO students for the questionnaire scale Satisfaction with previous educational programme

\begin{tabular}{|l|c|}
\hline & $\begin{array}{c}\text { Satisfaction with } \\
\text { previous educational } \\
\text { programme } \\
\text { (GL/MBO/HAVO) } \\
\mathrm{M}(\mathrm{Sd})\end{array}$ \\
\hline Former GL & $3.57(0.59)$ \\
\hline Former MBO & $3.35(0.67)$ \\
\hline Former HAVO & $3.54(0.53)$ \\
\hline
\end{tabular}

With respect to the third research question ('Do the three categories of students differ in the extent to which they feel prepared for their HBO programme in their previous educational programme?'), significant differences in mean scores between students from the three groups were found for the scales Study skills $(\mathrm{F}(2,269)=11.28 ; \mathrm{p} \leq 0.001)$, Theoretical subjects $(\mathrm{F}(2,269)=28.89 ; \mathrm{p} \leq 0.001)$, and Support in choosing HBO programme $(\mathrm{F}(2,269)=7.39$; $\mathrm{p} \leq 0.001)$.

With respect to the extent to which students felt prepared for their HBO programme in terms of study skills developed in their previous educational programme, former GL students scored higher than former MBO $(\mathrm{p} \leq 0.001)$ and former HAVO students $(\mathrm{p} \leq 0.001)$. No differences in this regard were found between former $\mathrm{MBO}$ and former HAVO students $(\mathrm{p}=0.78)$ (see also table 3$)$.

Regarding the extent to which students felt prepared for their $\mathrm{HBO}$ programme in terms of theoretical subjects addressed in their previous educational programme, former $\mathrm{MBO}$ students scored lower than former GL $(\mathrm{p} \leq 0.001)$ and former HAVO students $(\mathrm{p} \leq 0.001)$. No differences in this respect were found between former GL and former HAVO students ( $p=0.36)$ (see also table 3).

With respect to the extent to which students felt that they had received support in choosing a particular $\mathrm{HBO}$ programme in their previous educational programme, former HAVO students scored lower than former GL $(\mathrm{p} \leq 0.001)$ and former MBO students $(\mathrm{p} \leq 0.01)$. No differences in this regard were found between former GL and former MBO students $(\mathrm{p}=0.16)$ (see also table 3).

Regarding the extent to which students felt prepared for their HBO programme in terms of vocation-oriented aspects of their previous educational programme, no differences were found between former GL students and former MBO students $(F(1,188)=0.69 ; \mathrm{p}=0.41)$. Given the nature of their educational programme (general secondary education), for former HAVO students, vocation-oriented aspects were not applicable in their previous education; Therefore, former HAVO students were not included in this particular analysis (see also table $3)$. 
In the analyses, no significant effects of the covariate Gender were found for the various scales of the questionnaire.

Table 3: Mean scores (M) and standard deviations (Sd) of former GL, former MBO, and former HAVO students for the questionnaire scales Study skills, Theoretical subjects, Support in choosing HBO programme, and Vocation-oriented aspects

\begin{tabular}{|l|c|c|c|c|}
\hline & Study skills & $\begin{array}{c}\text { Theoretical } \\
\text { subjects }\end{array}$ & $\begin{array}{c}\text { Support in } \\
\text { choosing HBO } \\
\text { programme } \\
\mathrm{M}(\mathrm{Sd})\end{array}$ & $\begin{array}{c}\text { Vocation-orien- } \\
\text { ted aspects }\end{array}$ \\
$\mathrm{M}(\mathrm{Sd})$ & $\mathrm{M}(\mathrm{Sd})$ & $\mathrm{M}(\mathrm{Sd})$ \\
\hline Former GL & $3.59(0.54)$ & $3.34(0.62)$ & $2.99(0.73)$ & $3.65(0.78)$ \\
\hline Former MBO & $3.15(0.68)$ & $2.70(0.80)$ & $2.84(0.85)$ & $3.55(0.83)$ \\
\hline Former HAVO & $3.19(0.52)$ & $3.46(0.74)$ & $2.48(0.81)$ & Not applicable \\
\hline
\end{tabular}

\section{Conclusions and discussion}

The present study aimed to compare the experiences in the first HBO study year of students coming from different learning pathways to $\mathrm{HBO}$ (i.e., the continuing learning pathway GL, regular MBO at EQF4 level, and regular general secondary education at EQF4 level (HAVO)). One could argue that the more positive students are regarding their present $\mathrm{HBO}$ programme and the preparation for $\mathrm{HBO}$ in their previous educational programme, the higher their chances for a successful future HBO study career will be (cf. Mulder \& Cuppen, 2016; 2018; Mulder, 2018). Of course, in future research, these three learning pathways leading to HBO should be compared in terms of study success at HBO level as well, in order to be able to draw more definite conclusions on the effectiveness of the respective learning routes but the present study might already provide a first indication.

With respect to their motivation for school, school wellbeing, and school satisfaction, the three student groups had comparable mean scores. On average, students from the three groups were equally satisfied with their current $\mathrm{HBO}$ programme. The same pattern was found for perceived study success in their HBO programme. Former GL, former MBO, and former HAVO students reported that they were equally successful in their first HBO study year so far. Whether these perceptions are justified, should be checked through future research on students' learning performance and drop-out rates after one HBO study year.

Differences between the groups, however, were found when the experiences and perceptions of the students regarding their previous educational programme (either GL, or MBO, or HAVO) as preparation for $\mathrm{HBO}$ were concerned. These differences were especially clear for specific aspects of their previous education. Compared with students from the other two routes, former GL students mentioned that they had been better prepared in terms of development of study skills needed in HBO. Examples of study skills that had received more 
attention in the GL trajectory were e.g., presenting, doing research, reflecting, analysing, and using ICT. This finding is fully in line with the strong focus of the GL on developing learning and research competencies as required in $\mathrm{HBO}$.

Compared with the traditional VET (MBO) route to $\mathrm{HBO}$, former GL students felt better prepared in terms of the theoretical subjects addressed in their previous educational programme. In this regard, their level of theoretical preparation was comparable to that of former HAVO students. This pattern was found for almost all theoretical subjects (e.g., English and German languages, mathematics, biology, physics, and chemistry). In other words, when the theoretical level of education was concerned, the GL appeared to be highly comparable with the general secondary education (HAVO) route to HBO.

When the vocation-oriented aspects of education (cf. Jäppinen \& Maunonen-Eskelinen, 2012) were concerned, however, the GL appeared to be comparable with the MBO route to $\mathrm{HBO}$. Thus, the strong focus of the GL on study skills and theoretical level of the programme did not appear to be realized at the cost of the practical preparation of the students for their possible future jobs. At this point, it should be realized that the HAVO route does not offer any kind of vocation-oriented preparation given the nature of the educational programme (i.e., general secondary education). Moreover, former HAVO students scored lower than former GL and former MBO students with respect to the extent to which they felt that they had received support in choosing a particular $\mathrm{HBO}$ programme in their previous educational programme (cf. Kuijpers et al., 2011).

If one would combine the conclusions drawn above regarding the theoretical and the vocation-oriented aspects of the educational programme, one can indeed conclude that the GL integrates the best of both worlds (HAVO and MBO) for this specific category of students (students who combine a relatively high cognitive level with an affinity for practical, vocation-oriented assignments) as a preparation for an $\mathrm{HBO}$ programme (as already assumed in the section Theoretical Background) (see also Biemans et al., 2019). For these students, it is crucial that they are continuously challenged at the theoretical level and are confronted with assignments that refer to authentic professional contexts at the same time.

To summarize, the continuing learning pathway GL seems to combine the advantages of $\mathrm{MBO}$ and HAVO programmes for this particular group of students: Theoretical preparation for $\mathrm{HBO}$ at HAVO level combined with practical preparation at MBO level and systematic career orientation and guidance (cf. Kuijpers et al., 2011). Moreover, GL students seem to acquire study skills needed in $\mathrm{HBO}$ programmes to a higher extent than MBO and HAVO students. Thus, continuing learning pathways such as the GL can be a curriculum design solution for specific student groups to promote their transition to $\mathrm{HBO}$ (see also Biemans et al., 2019).

These conclusions are not just relevant for the Dutch VET context, but also for international policies and initiatives to increase the flexibilisation of transitions between educational 
subsystems. As mentioned in the Theoretical Background section of this article, this is an aspect that has attracted a great deal of attention in many countries for some time now (e.g., Hoelscher et al., 2008; Catterall et al., 2014; Harris \& Rainey, 2012). Our research shows the potential added value of integrating successive educational programmes and accelerating learning trajectories for specific target groups of students. Moreover, the combination of particular design features of these pathways should be attuned to the characteristics of these specific student subgroups (see for more details Biemans et al., 2019). In this respect, Jäppinen and Maunonen-Eskelinen (2012) also stressed the importance of student intake procedures and of shortening and integrating students' learning pathways as characteristics of effective learning routes. Thus, continuing learning pathways can facilitate and support students' transitions to higher educational levels within the VET system (and other educational systems) in other countries as well (see also Bradley, 2008; Catterall et al., 2014; Gorard et al., 2006; Watson, 2006).

As announced above, future research will focus on the effects of the previous educational pathway on the learning results and study careers of the students in $\mathrm{HBO}$ (see also Bradley, 2008; Gorard et al., 2006; Watson, 2006). Moreover, educational design principles and characteristics of the GL will be compared with those of other continuing learning pathways in (Dutch) VET to determine their effectiveness. In this way, further insights can be developed in the specific educational design characteristics that are most crucial for the effectiveness of these learning routes.

\section{References}

Association of Universities for Applied Sciences (2016). Feiten en cijfers. Afgestudeerden en uitvallers in het hoger beroepsonderwijs [Facts and numbers. Graduates and drop-outs from higher professional bachelor programmes]. Association of Universities for Applied Sciences.

Bathmaker, A. M., \& Thomas, W. (2009). Positioning themselves: An exploration of the nature and meaning of transitions in the context of dual sector FE/HE institutions in England. Journal of Further and Higher Education, 33(2), 119-130.

Biemans, H. J. A., De Bruijn, E., Den Boer, P. R., \& Teurlings, C. C. J. (2013). Differences in design format and powerful learning environment characteristics of continuing pathways in vocational education as related to student performance and satisfaction. Journal of Vocational Education and Training, 65(1), 108-126.

Biemans, H. J. A., Mariën, H., Fleur, E., Beliaeva, T., \& Harbers, J. (2019). Promoting students' transitions to successive VET levels through continuing learning pathways. Vocations and Learning, 12(2), 179-195.

Biemans, H. J. A., Mariën, H., Fleur, E., Tobi, H., Nieuwenhuis, L., \& Runhaar, P. (2016). Students' learning performance and transitions in different learning pathways to higher vocational education. Vocations and Learning, 9(3), 315-332. 
Biemans, H. J. A., Nieuwenhuis, L., Poell, R., Mulder, M., \& Wesselink, R. (2004). Competence-based VET in the Netherlands: Background and pitfalls. Journal of Vocational Education and Training, 56(4), 523-538.

Biemans, H. J. A., Wesselink, R., Gulikers, J., Schaafsma, S., Verstegen, J., \& Mulder, M. (2009). Towards competence-based VET: Dealing with the pitfalls. Journal of Vocational Education and Training, 61(3), 267-286.

Bradley, D. (2008). Review of Australian higher education: Final report. Commonwealth of Australia.

Brockmann, M., Clarke, L., Méhout, P., \& Winch, C. (2008). Competence-based vocational education and training (VET): The cases of England and France in a European perspective. Vocations and Learning, 1, 227-244.

Catterall, J., Davis, J., \& Yang, D. F. (2014). Facilitating the learning journey from vocational education and training to higher education. Higher Education Research \& Development, 33(2), 242-255.

Cedefop (2014). Terminology of European education and training policy: A selection of 130 terms (2nd ed.). Publications Office of the European Union.

Cedefop (2016). Spotlight on VET The Netherlands. Cedefop.

Dutch Educational Council (2014). Overgangen in het onderwijs [Transitions in education]. Dutch Educational Council.

Gorard, S., Smith, E., May, H., Thomas, L., Adnett, N., \& Slack, K. (2006). Review of widening participation research: Addressing the barriers to participation in higher education. A report to HEFCE. University of York, Higher Education Academy and Institute for Access Studies.

Harris, R., \& Rainey, L. (2012). Learning pathways between and within vocational and higher education: Towards a typology? Australian Educational Researcher, 39, 107-123.

Hoelscher, M., Hayward, G., Ertl, H., \& Dunbar-Goddet, H. (2008). The transition from vocational education and training to higher education: A successful pathway? Research Papers in Education, 23(2), 139-151.

Howell, D. C. (2010). Statistical methods for psychology (7th ed.). Cengage Learning.

Imandt, M., Van den Berg, E., Heyma, A., Mulder, J., Schipperheyn, R., Hermanussen, J., Groot, A., Petit, R., Glaudé, M., Pater, C., \& Van der Meijden, A. (2016). We zijn begonnen! Tweede meting monitor Vakmanschap- en technologieroutes [We have started! Second assessment monitor craftsmanship and technology routes]. SEO Economisch Onderzoek.

Jäppinen, A.-K., \& Maunonen-Eskelinen, I. (2012). Organisational transition challenges in the Finnish vocational education: Perspective of distributed pedagogical leadership. Educational Studies, 38(1), $39-50$.

Keeley, B. (2007). Human capital: How what you know shapes your life. OECD.

Kuijpers, M., Meijers, F., \& Gundy, C. (2011). The relationship between learning environment and career competencies of students in vocational education. Journal for Vocational Behavior, 78(1) $21-30$.

Lilleväli, U., \& Täks, M. (2017). Competence models as a tool for conceptualizing the systematic process of entrepreneurship competence development. Education Research International (Special issue Entrepreneurship education with impact: Opening the black box). https://doi.org/10.1155/2017/5160863

Mulder, J. (2016). Doorstroom MBO - HBO: studenten aan het woord. Over studiekeuze, verwachtingen en beleving [Transition MBO-HBO: Student stories. On study choice, expectations, and perception]. ECBO. 
Mulder, J. (2018, October). Verbeteren aansluiting mbo-hbo. Wat werkt? Resultaten van drie jaar onderzoek [Improving alignment middle-management VET programmes and higher professional bachelor programmes: What works? Results of three years of research]. Presentation at the closing symposium of the project 'Improved alignment MBO-HBO: What works?' Utrecht, The Netherlands.

Mulder, J., \& Cuppen, J. (2016). MBO-studenten die uitvallen op het HBO: wie zijn ze en waar vallen zij uit? Analyse van studentenstromen over periode 2005-2015 [MBO students who drop out in HBO: Who are they and when do they drop out? Analysis of student streams in the period 2005-2015]. ECBO.

Mulder, J., \& Cuppen, J. (2018). Verbeterde aansluiting mbo-hbo. Wat werkt? [Improved alignment middle-management VET programmes and higher professional bachelor programmes: What works?]. ResearchNed.

Mulder, M. (Ed.). (2017). Competence-based vocational and professional education: Bridging the worlds of work and education. Springer International Publishing Switzerland.

OECD (2010). Education of a glance. OECD.

Rasmussen, A., \& Nybye, N. (2013). EE: Progression model. Odense C, Denmark: The Danish Foundation for Entrepreneurship - Young Enterprise. Fonden for Entreprenørskab - Young Enterprise Danmark. www.ffe-ye.dk/media/44723/Progression-model-English.pdf

SCP (2016). Wikken en wegen in het hoger onderwijs [Considerations in higher education]. SCP.

Sneyers, E., \& De Witte, K. (2016). Doorstroom MBO-HBO en uitval in het HBO. Evidence-based aanbevelingen [Transition $\mathrm{MBO}-\mathrm{HBO}$ and drop-out in $\mathrm{HBO}$ : Evidence-based recommendations]. ECBO.

Van den Berg, N. (2013). Doorstroom tussen groen VMBO en MBO. Onderzoek naar relevante factoren en sturingsmogelijkheden [Transition between agricultural lower secondary pre-vocational schoolbased programmes and upper secondary VET programmes: Research on relevant factors and possibilities for governance]. AOC Council/Strix Aluco - Research \& Innovation.

Van den Berg, N., Nova, B., \& Potiek, S. (2017). Doorstroom in de groene beroepskolom [Transition in the green vocational column]. NRO.

Watson, D. (2006). New Labour and higher education. Perspectives: Policy and Practice in Higher Education, 10, 92-96.

Wheelahan, L. (2008). Neither fish nor fowl: The contradiction at the heart of Australian tertiary education. Journal of Access Policy and Practice, 5(2), 133-152.

Winters, A. (2012). Career learning in vocational education: Guiding conversations for career development. KU Leuven. 


\section{Biographical Notes}

Dr Harm J.A. Biemans is associate professor at the Education and Learning Sciences group of Wageningen University \& Research (The Netherlands). His research concentrates on competence development of (future) professionals and design and effects of corresponding learning environments and pathways.

Ing. Hans (J.B.A.) Mariën is researcher at IVA Education, a research institute at Tilburg University (The Netherlands) with a focus in the field of educational research. His research interests focus on school-to-work transitions (mainly in higher education) and learning performance at different educational levels.

Erik Fleur M.A. is researcher for the Executive Agency for Education (DUO), Dutch Department of Education, Culture, and Science. His research interests focus on transitions within the educational system and the relations between vocational and higher education.

Tanya Beliaeva M.Sc. is data scientist at the Executive Agency for Education (DUO), Dutch Department of Education, Culture, and Science. She does research on educational pathways of Dutch students from primary education to higher education.

Jan Harbers M.Sc. is educational developer at Terra, a Dutch VET institute in the agricultural domain. His research interests focus on the design of continuing learning pathways and effective transitions between successive educational levels. 